\title{
Preformulation Characterization of Griffithsin, a Biopharmaceutical Candidate for HIV Prevention
}

\author{
Lindsay F. Kramzer, ${ }^{1}$ Krystal T. Hamorsky, ${ }^{2,3,4}$ Phillip W. Graebing, ${ }^{1}$ Lin Wang, ${ }^{1}$ Joshua L. Fuqua, ${ }^{2,4,5}$ \\ Nobuyuki Matoba, ${ }^{2,4,5}$ Amanda B. Lasnik, ${ }^{2}$ Bernard J. Moncla, ${ }^{1,6}$ Junmei Zhang, ${ }^{7}$ \\ Kenneth E. Palmer, ${ }^{2,4,5}$ and Lisa C. Rohan ${ }^{1,6,7,8}$
}

Received 13 August 2020; accepted 13 January 2021; published online 24 February 2021

\begin{abstract}
Griffithsin (GRFT) has shown potent anti-HIV activity, and it is being developed as a drug candidate for HIV prevention. Successful implementation requires thorough understanding of its preformulation characterization. In this work, preformulation assessments were conducted to characterize GRFT and identify its degradation pathways under selected conditions of temperature, light, $\mathrm{pH}$, shear, ionic strength, and oxidation. Compatibility with vaginal fluid simulant, vaginal enzymes, Lactobacillus spp., and human cervicovaginal secretions was assessed. The purity, melting temperature, and HIV gp120binding affinity of GRFT stored at $4^{\circ} \mathrm{C}$ and $25^{\circ} \mathrm{C}$ in phosphate-buffered saline (PBS) were assessed for 2 years. Chemical modifications were evaluated by intact mass analysis and peptide sequencing. Excised human ectocervical tissue permeability and localization of GRFT were evaluated. Our results demonstrated GRFT to be safe and stable under all the preformulation assessment conditions studied except oxidative stress. When GRFT was exposed to hydrogen peroxide or human cervicovaginal secretion, methionine 78 in the protein sequence underwent oxidation. GRFT did not permeate through human cervical tissue but adhered to the superficial epithelial tissue. The 2-year stability study revealed no significant change in GRFT's aggregation, degradation, melting temperature, or gp120binding affinity despite a slow increase in oxidation over time. These studies elucidated desirable safety and bioactivity profile for GRFT, showing promise as a potential drug candidate for HIV prevention. However, susceptibility to oxidative degradation was identified. Effective protection of GRFT from oxidation is required for further development.
\end{abstract}

KEY WORDS: griffithsin; GRFT; preformulation; HIV prevention; oxidation.

\footnotetext{
${ }^{1}$ Magee-Womens Research Institute, 204 Craft Avenue, Room B509, Pittsburgh, Pennsylvania 15213, USA.

${ }^{2}$ James Graham Brown Cancer Center, University of Louisville School of Medicine, Louisville, Kentucky, USA.

${ }^{3}$ Department of Medicine, University of Louisville School of Medicine, Louisville, Kentucky, USA.

${ }^{4}$ Center for Predictive Medicine, University of Louisville School of Medicine, Louisville, Kentucky, USA.

${ }^{5}$ Department of Pharmacology and Toxicology, University of Louisville School of Medicine, Louisville, Kentucky, USA.

${ }^{6}$ Department of Obstetrics, Gynecology, \& Reproductive Sciences, School of Medicine, University of Pittsburgh, Pittsburgh, Pennsylvania, USA.

${ }^{7}$ Department of Pharmaceutical Sciences, School of Pharmacy, University of Pittsburgh, Pittsburgh, Pennsylvania, USA.

${ }^{8}$ To whom correspondence should be addressed. (e-mail: rohanlc@upmc.edu)
}

\section{INTRODUCTION}

Recent global statistics have revealed that in 2018, approximately 1.7 million people became infected with the human immunodeficiency virus (HIV), and there were 0.77 million deaths related to acquired immunodeficiency syndrome (AIDS) (1). Although these numbers are quite alarming, they have slowly and consistently decreased over the past decade due to the life-saving capacity of antiretroviral therapy. Despite these decreases, 38 million people are living with HIV worldwide.

Sexual transmission remains a leading cause of HIV infection. Abstinence, reduction of the number of sexual partners and concurrent sexual relationships, and correct, consistent condom use are highly effective against HIV acquisition but have been proven to be insufficient to combat this incurable disease. Therefore, an opportunity for strengthening the toolbox of HIV prevention methods exists. In July 2012, Truvada $\AA$, a once-a-day oral tablet containing fixed-dose reverse transcriptase inhibitors emtricitabine (200 
$\mathrm{mg}$ ) and tenofovir disoproxil fumarate $(300 \mathrm{mg})$, was approved by the US Food and Drug Administration (FDA) for pre-exposure prophylaxis (PrEP). However, oral PrEP may not prove a viable option for some people. Therefore, vaginally and rectally applied antiretroviral PrEP products, called microbicides, are under preclinical and clinical development. Agents being investigated as microbicide candidates include antiretrovirals that inhibit enzymes involved in different steps of a viral life cycle: viral entry and fusion, reverse transcriptase, integrase, and protease. These active pharmaceutical ingredients (APIs) include small molecules, peptides, proteins, and monoclonal antibodies. Additionally, various dosage forms are being investigated in order to expand prevention options. The dapivirine (reverse transcriptase inhibitor) vaginal ring is the product furthest along the microbicide development pipeline, which received a positive opinion from the European Medicines Agency in 2020.

Another encouraging microbicide candidate is Griffithsin (GRFT). GRFT was originally isolated from marine red alga Griffithsia sp. (2) and is now mass produced via expression in Nicotiana benthamiana leaves utilizing a recombinant tobacco mosaic virus (TMV) vector system (3). It exists as a homodimer under native conditions, and each monomer consists of 121 amino acids with a molecular mass of 12.7 kilodaltons (kDa) (2). GRFT is a carbohydrate-binding protein or lectin that exhibits broad-spectrum activities against a variety of viruses, including HIV (2-7), herpes simplex virus type 2 (HSV-2) $(8,9)$, human papillomavirus (HPV) (8), Nipah (10), hepatitis C (HCV) $(11,12)$, Japanese encephalitis virus (JEV) $(13,14)$, coronaviruses such as severe acute respiratory system coronavirus (SARS-CoV) (15) and Middle East respiratory syndrome coronavirus (MERS-CoV) (16), and some other viruses as reviewed elsewhere (17-19).

Among the long list of viruses, HIV is likely the most studied target for GRFT (2-7). GRFT binds to viral gp120, an HIV envelope glycoprotein, to elicit its anti-HIV activity (2). Both the native and recombinant forms of this lectin potently inhibit CXCR4- and CCR5-tropic HIV infection and transmission in vitro, requiring concentrations only in the picomolar range (20). This high potency can be explained by GRFT's ability to have tight multivalent interactions with high-mannose N-linked glycans present on HIV envelope glycoproteins $(21,22)$. GRFT has also been found to be safe in human cervical explants and in the rabbit vaginal irritation model (3). Given GRFT's favorable preclinical bioactivity and safety profile, GRFT is being developed as a microbicide candidate $(8,23-30)$. To support such developmental efforts, preformulation studies of GRFT were warranted.

Preformulation evaluations are essential to pharmaceutical research and development (R\&D). Within these assessments, the prospective API is exposed to a variety of forced conditions (i.e. $\mathrm{pH}$, acidic and alkaline hydrolysis, photolysis, oxidation, temperature, ionic strength agitation, and freezing and thawing cycles) to determine its instabilities, if any. These experiments provide us critical information on processing, storage, and usage conditions to avoid or protect the product; therefore, they are paramount in preparation for drug formulation. For a proteinaceous API such as GRFT, potential conformational changes (like denaturation or aggregation) under the above conditions should also be evaluated. A potential vaginal microbicide should be further assessed under conditions similar to the vaginal environment. These include the $\mathrm{pH}$ of this environment as well as the presence of commensal bacteria such as Lactobacillus spp., enzymes such as lysozyme and aminopeptidase (31-33), a plethora carbohydrate cleaving enzymes including sialidases $(34,35)$, and other polypeptides, salts, organic acids, peroxides, and oligosaccharides $(36,37)$. Tissue permeability assesses drug absorption and distribution. Furthermore, realtime stability studies provide valuable information about the physicochemical properties of drug substance and support preformulation evaluations.

In this work, we focused on GRFT preformulation efforts to determine the stability of GRFT in several forced conditions, to describe the degradation pathways, and to assess its real-time stability in phosphate-buffered saline (PBS) over a 2-year period. These evaluations were performed to provide information needed to develop GRFT as a drug candidate, especially as a vaginally delivered drug for HIV prevention.

\section{MATERIALS AND METHODS}

\section{Materials}

Recombinant GRFT drug substance was supplied by Kentucky Bioprocessing LLC (Owensboro, KY). The protein was supplied in a solution of PBS $(12 \mathrm{mg} / \mathrm{mL}$ for 2-year stability study; $10 \mathrm{mg} / \mathrm{mL}$ for all other assessments). PBS $10 \times$ molecular biology grade ( $\mathrm{pH}$ 7.4) was purchased from Mediatech, Inc. (Manassa, VA). Acetonitrile (ACN), trifluoroacetic acid (TFA), sodium acetate, formic acid, phosphate acid, potassium phosphate monobasic, potassium phosphate dibasic, Tris, hydrochloric acid $(\mathrm{HCl})$, and sodium hydroxide $(\mathrm{NaOH})$ were obtained from Fisher Scientific (Pittsburgh, PA). Hydrogen peroxide $\left(\mathrm{H}_{2} \mathrm{O}_{2}, 30 \%\right)$, disodium ethylenediaminetetraacetic acid (EDTA), D- $\alpha$ tocopheryl polyethylene glycol 1000 succinate (vitamin E TPGS), ascorbic acid, methionine, glutathione, cysteine, aminopeptidase, lysozyme, and proteinase $\mathrm{K}$ were obtained from Sigma (St. Louis, MO). A MilliQ (Millipore; Milford, MA) water filtration system operating at $18.2 \mathrm{M} \Omega \mathrm{cm}$ was used for water.

\section{Physical and Chemical Stability Assessments}

\section{Thermal Stability}

GRFT $(450 \mu \mathrm{g} / \mathrm{mL})$ in MilliQ water was exposed to $5^{\circ} \mathrm{C}$, $25^{\circ} \mathrm{C} / 60 \% \mathrm{RH}$ (relative humidity), $30^{\circ} \mathrm{C} / 65 \% \mathrm{RH}, 40^{\circ} \mathrm{C} /$ $75 \% \mathrm{RH}$, and $65^{\circ} \mathrm{C}$ in controlled temperature/humidity Carson 6010 environmental chambers for 28 days (RH control at $5^{\circ} \mathrm{C}$ and $65^{\circ} \mathrm{C}$ is not available). GRFT concentration was monitored via reverse-phase high-performance liquid chromatography (RP-HPLC) with fluorescence detection.

\section{Ionic Strength}

GRFT solutions were prepared at concentrations ranging from 31.25 to $250 \mu \mathrm{g} / \mathrm{mL}$ in water and phosphate buffers ( $\mathrm{pH}$ 4, 7, and 10) at low (50 mOsm/ $/ \mathrm{kg})$ and high $(500 \mathrm{mOsm} / \mathrm{kg})$ osmolality. UV spectroscopy with a Cary 50 Bio UV-Visible 
Spectrophotometer was employed for this stability evaluation.

\section{Photolysis}

GRFT $(450 \mu \mathrm{g} / \mathrm{mL})$ in MilliQ water was exposed to $30^{\circ} \mathrm{C} / 65 \% \mathrm{RH}$ for 28 days. Experimental containers were exposed to the lamps within this environmental chamber. Negative control containers were protected from light with aluminum foil. GRFT concentration was monitored via RPHPLC.

\section{Freeze/Thaw Cycling}

GRFT $(450 \mu \mathrm{g} / \mathrm{mL})$ in MilliQ water was exposed to five freeze/thaw cycles at both $-80^{\circ} \mathrm{C} / 25^{\circ} \mathrm{C}$, and $-20^{\circ} \mathrm{C} / 25^{\circ} \mathrm{C}$. GRFT concentration was monitored via RP-HPLC.

Agitation

GRFT $(450 \mu \mathrm{g} / \mathrm{mL})$ was subjected to $72 \mathrm{~h}$ of agitation (Vortex Genie®-2, speed 3) at $25^{\circ} \mathrm{C}$. Its concentration was monitored via RP-HPLC.

\section{pH Stability}

The effect of $\mathrm{pH}$ on the stability of GRFT $(450 \mu \mathrm{g} / \mathrm{mL})$ was evaluated at $25^{\circ} \mathrm{C}$ with buffer solutions over the $\mathrm{pH}$ range of 3 to 9 as follows: $10 \mathrm{mM}$ Formate $\mathrm{pH} \mathrm{3,10 \textrm {mM }}$ acetate $\mathrm{pH} 4,10 \mathrm{mM}$ phosphate $\mathrm{pH} 4,10 \mathrm{mM}$ acetate $\mathrm{pH}$, $10 \mathrm{mM}$ phosphate $\mathrm{pH} 7,10 \mathrm{mM}$ phosphate $\mathrm{pH} 8$, and $10 \mathrm{mM}$ Tris $\mathrm{pH}$ 9. GRFT concentration was monitored via RPHPLC.

\section{Acid/Base Hydrolysis}

To determine degradation due to hydrolysis, GRFT was prepared at $450 \mu \mathrm{g} / \mathrm{mL}$ in $1 \mathrm{~N} \mathrm{HCl}$ or $1 \mathrm{~N} \mathrm{NaOH}$, with storage at ambient temperature. GRFT concentration was monitored via RP-HPLC over $30 \mathrm{~h}$.

\section{Oxidation}

Oxidation of GRFT was evaluated by exposing GRFT to $0.02 \% \mathrm{H}_{2} \mathrm{O}_{2}$. The final concentration of GRFT was $450 \mu \mathrm{g} /$ $\mathrm{mL}$ and was stored at ambient temperature. Samples were assayed by RP-HPLC every $30 \mathrm{~min}$ for a total of approximately $24 \mathrm{~h}$. The oxidative by-products were fraction collected and then subjected to mass spectrometric analysis and gp120 binding via enzyme-linked immunosorbent assay (ELISA).

\section{Protection Against Oxidation}

We screened six antioxidants that are commonly used in pharmaceutical products, including methionine (0.09 and $0.25 \%)$, cysteine $(0.09$ and $0.25 \%)$, glutathione $(0.09$ and $0.25 \%)$, vitamin E TPGS $(0.009 \%)$, EDTA $(0.05 \%)$, and ascorbic acid $(0.1 \%)$. The stability of GRFT after addition of an antioxidant was monitored via HPLC.

\section{Stability Under Biologically Relevant Conditions}

\author{
Stability in Vaginal Fluid Simulant
}

Vaginal fluid simulant (VFS) was manufactured as previously described (38). GRFT $(450 \mu \mathrm{g} / \mathrm{mL})$ was stored in VFS at $37^{\circ} \mathrm{C}$ for 4 days. GRFT concentration was monitored with RP-HPLC.

\section{Susceptibility to Cervicovaginal Enzymes}

GRFT was exposed to three enzymes commonly present in human cervicovaginal secretion environment (31-33): aminopeptidase $100 \mathrm{U} / \mathrm{mL}$, lysozyme 100,000 U/mL, and proteinase K $100 \mathrm{U} / \mathrm{mL}$. GRFT $(450 \mu \mathrm{g} / \mathrm{mL})$ was incubated with each enzyme separately for up to $6 \mathrm{~h}$ at $37^{\circ} \mathrm{C}$. GRFT concentration was monitored via RP-HPLC.

\section{Compatibility with Commensal Vaginal Bacteria}

GRFT stock material was tested for compatibility with commensal vaginal bacteria utilizing the Standard Microbicide Safety Test as previously described (39). Strains tested were Lactobacillus crispatus ATCC 33197, L. jensenii ATCC 25258, and L. jensenii LBP 28Ab, which are present within normal human vaginal fluid. Bacterial suspensions were prepared in $\mathrm{N}$-(2-acetamido)-2-aminoethanesulfonic acid buffer. To determine the effect of GRFT on the lactobacilli viability, GRFT was added into the suspensions and incubated at $37^{\circ} \mathrm{C}$ for $30 \mathrm{~min}$. Samples were taken at time 0 and $30 \mathrm{~min}$. Aliquots of each sample after the treatment were seeded on the surfaces of agar plates. The plants were incubated at $37^{\circ} \mathrm{C}$ for $24 \mathrm{~h}$. The number of viable bacterial cells was counted for each plate, and colony-forming unit per $\mathrm{mL}(\mathrm{CFU} / \mathrm{mL})$ was calculated. The average CFU value count at each time point was $\log$-transformed $(\log (\mathrm{CFU} / \mathrm{mL}))$. Lactobacillus viability was calculated as the $\log (\mathrm{CFU} / \mathrm{mL})$ difference between the log counts at time 0 and after $30 \mathrm{~min}$ of treatment. In comparison with the controls, a decrease of Lactobacillus viability by more than 10 -fold was considered as an undesirable effect.

\section{Stability in Human Cervicovaginal Lavage}

Human cervicovaginal lavage (CVL) was obtained from the University of Pittsburgh under IRB Protocol PRO11020218. CVL was collected from healthy, HIVnegative premenopausal women. Samples were stored at $-80^{\circ} \mathrm{C}$ until they were thawed for immediate testing. GRFT was exposed to human CVL at room temperature $\left(25^{\circ} \mathrm{C}\right)$ and monitored via RP-HPLC every $30 \mathrm{~min}$ for approximately $2.5 \mathrm{~h}$ due to volume constraints. The oxidized GRFT products from the CVL exposure were fraction collected and further characterized via intact mass analyses and HIV-1 gp120 binding.

\section{Permeability Through Human Cervical Tissue}

Excised human cervical tissue was obtained from the University of Pittsburgh Health Sciences Tissue Bank under the University of Pittsburgh Institutional Review Board 
(IRB) Protocol PRO09110431. Tissue specimens were collected from women undergoing hysterectomies for noncervical issues. A section of each tissue was retained for histological evaluation. After removal of the excess stromal tissue, the ectocervical epithelial tissue was placed between two pre-measured slides for thickness measurement.

A Franz cell system (PermeGear) was utilized for these tissue permeability studies. Tissue sections were placed between the donor and receptor compartments of the Franz cell with the epithelial side toward the donor compartment. This set-up was maintained at $37^{\circ} \mathrm{C}$ throughout the experiment. The receptor compartment was filled with PBS1X. The donor compartment was loaded with $450 \mu \mathrm{L}$ of $2.25 \mathrm{mg} / \mathrm{mL}$ GRFT or GRFT-AlexaFluor488 drug substance in PBS1X. At the beginning of the experiment, $50 \mu \mathrm{L}$ was removed from the donor compartment. At predetermined time points, $200 \mu \mathrm{L}$ was removed from the receptor chamber and the same volume of fresh PBS1X was added for replacement. These samples were held at $2-8^{\circ} \mathrm{C}$ until analyzed by RP-HPLC.

All tissues were processed for paraffin sectioning. The tissue sections were embedded into paraffin blocks using the Leica EG 1160 embedding station. Tissues were then sectioned at five microns $(5 \mu \mathrm{m})$ with the Olympus CUT 4060 microtome and placed on slides for further processing or staining procedures.

GRFT was tagged using an Alexa Fluor® 488 Protein Labeling Kit from Invitrogen. GRFT-AlexaFluor488 has been previously used in tissue and cellular studies (40). The tissue sections on the slides were deparaffinized. Then $4^{\prime}, 6-$ diamidino-2-phenylindole (DAPI; VECTASHIELD HardSet Mounting Medium with DAPI) was used for fluorescence visualization of cellular nuclei (tissue orientation aid) and to seal the cover slip. Areas on the tissue containing GRFTAlexaFluor488 appeared bright green. Nuclei of epithelial cells appeared blue/purple.

Additionally, tissue sections were developed to determine GRFT tissue localization for the permeability experiments performed with unlabeled GRFT. Unlabeled GRFT was used for this experiment because the AlexaFluor488 dye compound has a molecular weight of approximately 900, which may impact GRFT permeability due to increased size or conformation of GRFT-AlexaFluor488. Slides were heated at $60^{\circ} \mathrm{C}$ for $10 \mathrm{~min}$. The tissue sections on the slides were deparaffinized. The following antibodies and staining components were used in this procedure: polyclonal primary goat anti-GRFT and biotinylated rabbit anti-goat IgG secondary antibody. Avidin-HRP (Vector Labs) and DAB (3,3'-diaminobenzidine; ImmPACT DAB HRP Substrate, Vector Labs) were applied and incubated for $1 \mathrm{~min}$ at RT.

To determine the tissue safety (any gross morphological changes) of GRFT application on human cervical epithelial tissue, hematoxylin and eosin (H\&E) were used. Hematoxylin stains the nuclei of cells purple. Eosin stains the other structures of the tissue section red/pink.

Microscopy was performed with a Zeiss Axioskop 40 Microscope equipped with a Prior Scientific Lumen 200 Fluorescence Illumination System (for fluorescence imaging). Micrographs were obtained with an AxioCam MRc 5 color camera and AxioVision software. For fluorescence detection, the FITC filter and the DAPI filter were used. AlexaFluor488 and FITC have comparable excitation and emission wavelengths. Micrographs utilizing these two fluorescence filters were overlaid. All micrographs were taken with a $\times 20$ objective.

\section{Long-Term Stability Assessments}

GRFT was filled into $5 \mathrm{~mL}$ PETG vials at a concentration of $12 \mathrm{mg} / \mathrm{ml}$ in PBS and stored at either $4^{\circ} \mathrm{C}$ or $25^{\circ} \mathrm{C}$. At each time point $(0,1,3,6,9,12,18$, and 24 months $)$, a fresh vial of GRFT from both conditions was characterized using analytical methods of RP-HPLC, SEC-HPLC, DSF, gp120 ELISA, and SPR as described below.

\section{Analytical Methods}

\section{Reverse-Phase (RP) High-Performance Liquid Chromatography}

The HPLC system (Waters Corporation; Milford, CA) was equipped with an autosampler model 717 plus, a quaternary pump controller model 600, and a fluorescence detector model 2487, using an excitation wavelength of $273 \mathrm{~nm}$ and an emission wavelength of $303 \mathrm{~nm}$. Separation of GRFT from by-products/degradants was achieved using a Phenomenex

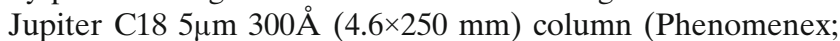
Torrance, CA) protected by a Gemini C18 $(4 \times 3 \mathrm{~mm})$ guard cartridge (Phenomenex; Torrance, CA), both maintained at ambient temperature. The mobile phase gradient consisted of mobile phase A $(0.1 \%$ TFA in water $(\mathrm{v} / \mathrm{v}))$, and mobile phase $\mathrm{B}(0.05 \%$ TFA in $\mathrm{ACN}(\mathrm{v} / \mathrm{v}))$ pumped at a flow rate of 1.0 $\mathrm{mL} / \mathrm{min}$. The gradient was proportioned as follows (minute, $\%$ B): 0,$12 ; 15,20 ; 16,50$; and 20, 12 . Linearity of the detector response curve was 10 to $500 \mu \mathrm{g} / \mathrm{mL}$.

\section{Mass Spectrometry}

GRFT and its oxidative by-products from the $\mathrm{H}_{2} \mathrm{O}_{2}$ exposure were subjected to intact mass analyses via mass spectrometry to determine their molecular weights. Prior to analysis, $5 \%$ formic acid was added to each sample. For intact mass analysis, a Bruker micrOTOF with a capillary ESI source and a Dionex U3000 HPLC system were utilized. The HPLC column was a PRLP-S column (Thermo Fisher, 1000 $\AA$, $5 \mu \mathrm{m}, 100 \times 0.3 \mathrm{~mm}$ ) maintained at $40^{\circ} \mathrm{C}$ temperature. The mobile-phase gradient consisted of mobile phase A $(2.5 \%$ acetonitrile $/ 0.1 \%$ formic acid in water) and mobile phase $\mathrm{B}$ ( $80 \%$ acetonitrile/20\% water $/ 0.1 \%$ formic acid) pumped at a flow rate of $3.5 \mu \mathrm{L} / \mathrm{min}$. The gradient was proportioned as follows (minute, \%B): 0, 5; 10, 30; 50, 75; 65, 100; and 75, 5 . The intact mass analysis was performed in positive ion mode, with the acquisition range of $\mathrm{m} / \mathrm{z} 50-3000$. The $\mathrm{m} / \mathrm{z}$ values were converted into molecular mass values with the MaxEnt Deconvolution program. The mass accuracy of this instrument is $0.01 \%$ of the analyte mass. Therefore, for GRFT parent monomer of $12.7 \mathrm{kDa}$, the mass accuracy should be 12 Da. For GRFT parent homodimer of $25.4 \mathrm{kDa}$, the mass accuracy should be 2-4 Da.

One of the GRFT oxidative by-products also underwent peptide sequencing to determine the site(s) of oxidation. Prior to this analysis, samples were concentrated, denatured 
with $1 \%$ Rapigest, and diluted with $100 \mathrm{mM}$ ammonium bicarbonate to $0.1 \%$ Rapigest. After dilution, protease (trypsin or chymotrypsin) at 2:1 protein/protease (w/w) was added to each sample. Following an overnight incubation at $37^{\circ} \mathrm{C}, 5 \%$ formic acid was added to each sample to hydrolyze the Rapigest. The samples were then concentrated, the Rapigest was removed, and the sample was desalted with zip tips (Millipore). For peptide sequencing analysis of GRFT stock, a Thermo LTQ XL and a Dionex U3000 HPLC system were utilized. For peptide sequencing of Peak C, a Thermo LTQ Orbitrap XL and a Waters nano-Acquity UPLC system were used. The same column system was used for both: PicoChip ReproSil-Pur C18-AQ $3 \mu \mathrm{m} 120 \AA$ HPLC column maintained at ambient temperature. The mobile phase gradient consisted of mobile phase A $(0.1 \%$ formic acid in water) and mobile phase B ( $0.1 \%$ formic acid in acetonitrile) pumped at a flow rate of $300 \mathrm{~nL} / \mathrm{min}$. The gradient was proportioned as follows (minute, \%B): 0, 2; 50, 40; 51, 95; 52, $95 ; 52.5,2$; and $60,2$.

\section{SEC High-Performance Liquid Chromatography}

Size exclusion (SEC) was performed on a Beckman Coulter System Gold HPLC. An aliquot of $10 \mu \mathrm{L}$ GRFT $\left(4^{\circ} \mathrm{C}, 25^{\circ} \mathrm{C}\right.$ and reference standard) was injected onto an SEC column (TSKgel SuperSW3000, 4.6 mm I.D. $\times 30 \mathrm{~cm}, 4 \mu \mathrm{m}$; TOSOH Biosciences, LLC; TSKgel guardcolumn SuperSW, $4.6 \mathrm{~mm}$ I.D. $\times 30 \mathrm{~cm}, 4 \mu \mathrm{m}$; TOSOH Biosciences, LLC) equilibrated in running buffer (100 $\mathrm{mM}$ sodium phosphate [pH 7.2], $150 \mathrm{mM}$ sodium chloride, $0.05 \%$ sodium azide). After injection, running buffer was applied to the column at flow rate of $0.2 \mathrm{~mL} / \mathrm{min}$ for $30 \mathrm{~min}$. Based on the percent purity of the GRFT peak, this SEC-HPLC method has an intermediate precision of $<1 \%$ coefficient of variation.

$D S F$

The melting temperature $\left(T_{m}\right)$ of GRFT, at a final concentration of $62.5 \mu \mathrm{M}$ in PBS, was determined on a BioRad iQ5 multicolor real-time PCR system. Sypro orange (Molecular Probes) at a final concentration of $\times 5$ was added to GRFT and was heated from 20 to $95^{\circ} \mathrm{C}$ in $0.2^{\circ} \mathrm{C}$ increments at intervals of $15 \mathrm{~s} . T_{m}$ values were determined by the vertex of the first derivative of the relative fluorescence unit (RFU) values.

\section{gp120 ELISA}

The binding between GRFT or its oxidative by-products and gp120 were determined employing a gp120 ELISA as previously described $(2,3)$ with the minor modification of using anti-GRFT goat polyclonal instead of anti-GRFT rabbit polyclonal. Briefly, serial dilutions of a GRFT sample were added to gp120-coated plates, and GRFT was visualized by goat anti-GRFT primary antibody and HRP-labeled rabbit anti-goat secondary antibody. Optical density at $450 \mathrm{~nm}$ was measured. The data was plotted as the log concentration of GRFT on the X-axis and the OD on the Y-axis in GraphPad Prism 5.0. The $\log$ (agonist) vs. response-variable slope (four parameters) was used to fit the curve and calculate $\mathrm{EC}_{50}$ values.
$S P R$

The equilibrium dissociation constant $\left(K_{d}\right)$ of GRFT to gp120 was measured using a Biacore X100 2.0 instrument at ambient temperature. For each sample $\left(4^{\circ} \mathrm{C}, 25^{\circ} \mathrm{C}\right.$, and reference standard), the assay was performed in triplicate. Recombinant biotinylated gp120 (Du151, HIV1/Clade C, Immune-tech no. IT-001-139p-Biotin) at a concentration of 1 $\mu \mathrm{g} / \mathrm{mL}$ was immobilized on a SA sensor chip (Biacore no. BR-1000-32) in $10 \mathrm{mM}$ sodium acetate $\mathrm{pH} 5.5$ at a flow rate of $5 \mu \mathrm{L} / \mathrm{min}$ and a contact time of $150 \mathrm{~s}$. A reference flow cell was utilized to correct response contributions such as bulk shifts that occur equally in the sample and reference flow cells. Serial dilutions of GRFT $(125,62.5,31.25,15.625$, and $7.8125 \mathrm{nM}$ ) were made in running buffer (HBS-EP, GE Healthcare) and injected, at a flow rate of $5 \mu \mathrm{L} / \mathrm{min}$, for a contact time of $60 \mathrm{~s}$ and a dissociation time of $600 \mathrm{~s}$. Between sample injections, the system was washed with running buffer, and the immobilized surface was regenerated with $10 \mathrm{mM}$ glycine- $\mathrm{HCl} \mathrm{pH} 2.0$ for a contact time of $30 \mathrm{~s}$. Each set of data was analyzed using the steady-state affinity analysis in the Biacore X100 2.0 evaluation software.

\section{Statistical Analyses}

GRFT concentration over time is reported as GRFT recovery (\% of time zero) \pm standard deviation for all of the analyses involving GRFT stability assayed with RP-HPLC. GRFT recovery ( $\%$ of time 0 ) is calculated as [GRFT, $\mu \mathrm{g} / \mathrm{mL}$ ] at the specified time point/[GRFT, $\mu \mathrm{g} / \mathrm{mL}]$ at time $0 \times 100$. This data was analyzed using one-way analysis of variance (ANOVA). $p$ values of $<0.05$ were considered statistically significant.

\section{RESULTS}

\section{Physical and Chemical Stability}

\section{Thermal and Photolytic Stability}

The GRFT recovery over 28 days exposure was calculated for the following thermal conditions: $5^{\circ} \mathrm{C}, 25^{\circ} \mathrm{C} /$ $60 \% \mathrm{RH}, 30^{\circ} \mathrm{C} / 65 \% \mathrm{RH}, 40^{\circ} \mathrm{C} / 75 \% \mathrm{RH}$, and $65^{\circ} \mathrm{C}$. For the four lower thermal conditions, the GRFT loss was only $10 \%$ of time 0 , and no significant difference was observed between any of these four conditions $(p=0.07)$ at day 28 (Fig. 1). In contrast, the recovery of GRFT at $65^{\circ} \mathrm{C}$ (the highest temperature studied) quickly declined within 1 day, and the protein became undetectable at 14 days exposure (detectable up to 7 days exposure). No GRFT degradation/product peaks were detected.

\section{Ionic Strength}

The effect of ionic strength on the stability of GRFT was evaluated by UV-spectroscopy. No pronounced increases in absorbance were evident for $250 \mu \mathrm{g} / \mathrm{mL}$ of GRFT at either low or high osmolality (Fig. 2). In addition, GRFT was tested at different concentrations, and it remained stable under all testing conditions (between 31.25 and $250 \mu \mathrm{g} / \mathrm{mL}$ ). These 


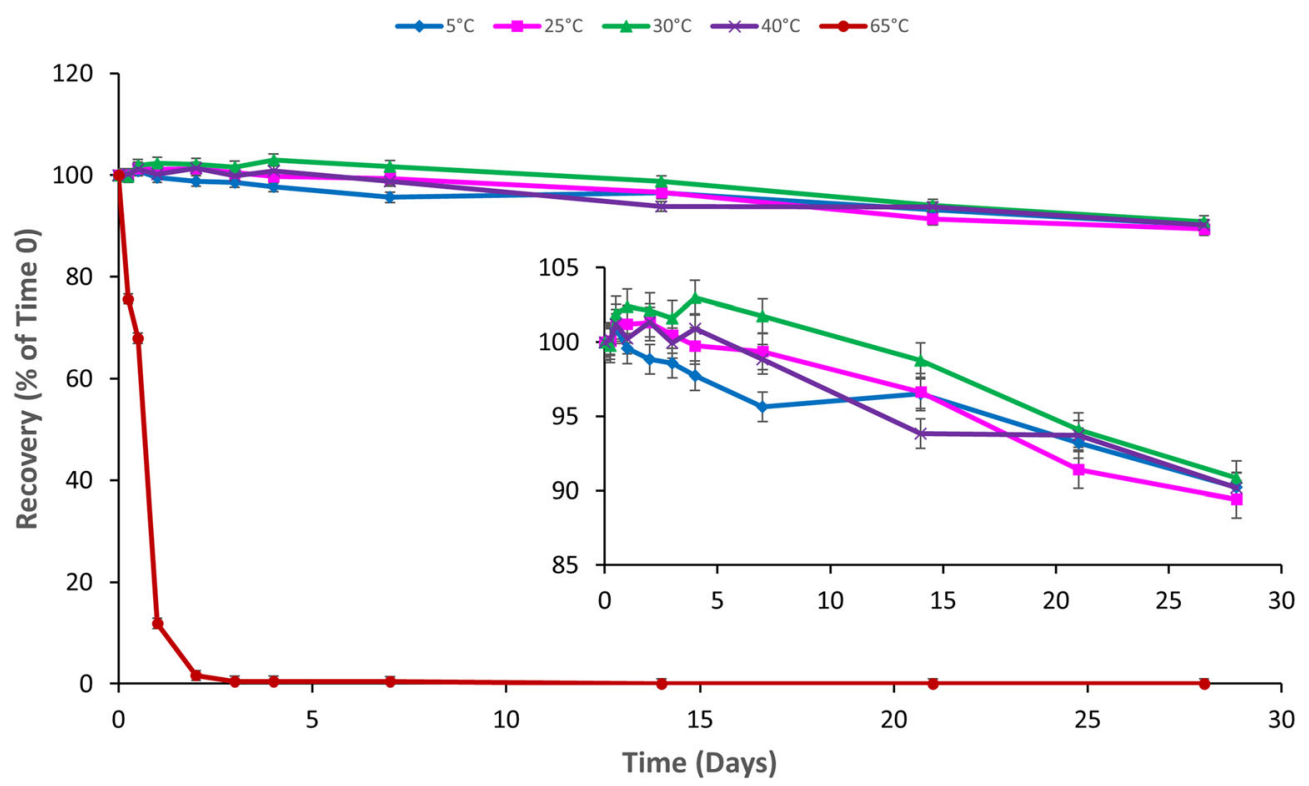

Fig. 1. GRFT thermal stability. GRFT $(450 \mu \mathrm{g} / \mathrm{mL})$ in Milli-Q water was exposed to $5{ }^{\circ} \mathrm{C}, 25{ }^{\circ} \mathrm{C} / 60 \% \mathrm{RH}$, $30{ }^{\circ} \mathrm{C} / 65 \% \mathrm{RH}, 40{ }^{\circ} \mathrm{C} / 75 \% \mathrm{RH}$, and $65{ }^{\circ} \mathrm{C}$ in controlled temperature/humidity Carson 6010 environmental chambers for 28 days. Relative humidity (RH) control at $5{ }^{\circ} \mathrm{C}$ and $65{ }^{\circ} \mathrm{C}$ was not available. GRFT concentration was monitored via HPLC with fluorescence detection. The inset is included to better display the thermal stability trends at the four lower temperature conditions

results indicate that insoluble protein aggregates were not formed under these conditions.

\section{Freeze/Thaw Cycling and Agitation}

After five freeze/thaw cycles at $-80^{\circ} \mathrm{C} / 25^{\circ} \mathrm{C}$ and $-20^{\circ} \mathrm{C} /$ $25^{\circ} \mathrm{C}$, the GRFT recovery was $102.0 \pm 0.23 \%$ and $99.0 \pm$ $0.90 \%$, respectively. After $72 \mathrm{~h}$ of agitation, the GRFT recovery remained at $97 \pm 0.88 \%$. Therefore, GRFT was not prone to physical instability from freeze/thaw cycling, and agitation or shaking during formulation or sample processing.

\section{pH Stability}

GRFT's stability in $\mathrm{pH}$ buffered solutions was initially monitored for 5 days. GRFT showed $>95 \%$ recovery in $\mathrm{pH} 3$ formate, $\mathrm{pH} 5$ acetate, $\mathrm{pH} 7$ phosphate, $\mathrm{pH} 8$ phosphate, and $\mathrm{pH} 9$ Tris buffers. However, the GRFT recovery in $\mathrm{pH} 4$ acetate buffer declined to $88.1 \%$ of time 0 concentration on day 5 (Fig. 3). The stability analysis was therefore extended to 20 days for further assessment. GRFT was found to remain $>90 \%$ recovery in $\mathrm{pH} 3,5,7,8$ and 9 buffered solutions throughout the storage period (not shown). In contrast, recovery in $\mathrm{pH} 4$ acetate buffer declined to $79 \%$ on day 20 . In $\mathrm{pH} 4$ phosphate buffer, GRFT recovery decreased to $95 \%$ after 3 days. Further testing in this buffer was not pursued.

\section{Acid/Base Hydrolysis}

GRFT showed stability with $>97 \%$ recovery when stored in $1 \mathrm{~N}$ solutions of both $\mathrm{HCl}$ and $\mathrm{NaOH}$ for $30 \mathrm{~h}$ (data not shown).

\section{Biologically Relevant Assessments}

\section{Stability in Vaginal Fluid Simulant}

The stability of GRFT in vaginal fluid simulant was monitored. This biological fluid simulant was utilized due to its historical use in in vitro experiments of vaginally applied products. GRFT drug substance remained stable over 4 days $(p=0.08)$, with recovery of $98 \% \pm 1.4 \%$ (Fig. $4 \mathrm{a})$.

\section{Susceptibility to Cervicovaginal Enzymes}

Given its proteinaceous nature, GRFT has the potential to be enzymatically degraded. In order to establish the cervicovaginal enzymatic degradation potential of GRFT, this protein was exposed to enzymes commonly present in the normal human vaginal environment (31-33). GRFT was found to be a stable protein and was not highly prone to enzymatic degradation of aminopeptidase, lysozyme, or proteinase K. Recovery of GRFT from these individual enzyme solutions ranged from 90 to $103 \%$ after $6 \mathrm{~h}$ of incubation at $37^{\circ} \mathrm{C}$ (Fig. 4b).

\section{Permeability Through Human Cervical Tissue}

GRFT-AlexaFluor488 permeability was performed on six pieces of human cervical tissues. To confirm findings obtained from the GRFT-AlexaFluor488 experiments, unlabeled GRFT permeability was performed on five human cervical tissue specimens (sample size limited due to tissue availability). All tissue samples were obtained from females in the age range of 30-50 years.

GRFT recovery from the donor compartment (mean \pm $\mathrm{SD})$ at the end of the experiment $(6 \mathrm{~h})$ was $98.0 \% \pm 4.5 \%$ and $101.3 \% \pm 6.8 \%$ for GRFT-AlexaFluor488 and unlabeled 
a

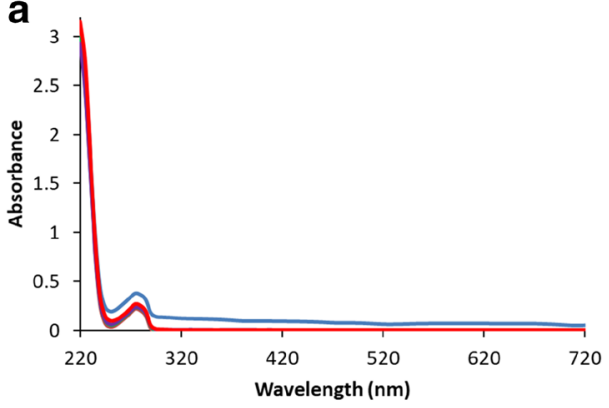

b

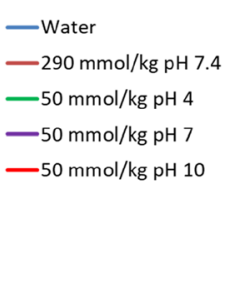

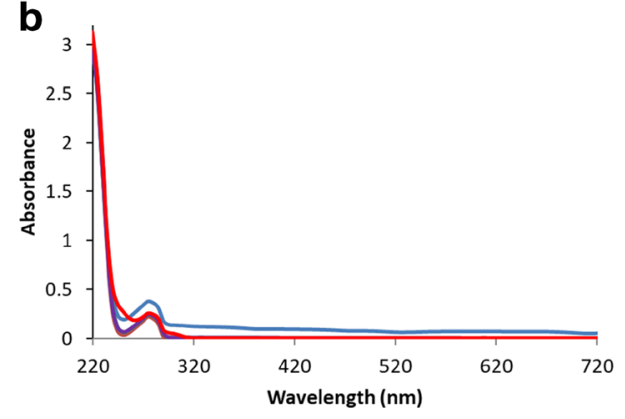

-Water

$-290 \mathrm{mmol} / \mathrm{kg} \mathrm{pH} 7.4$

$-500 \mathrm{mmol} / \mathrm{kg} \mathrm{pH} 4$

- $500 \mathrm{mmol} / \mathrm{kg} \mathrm{pH} 7$

$-500 \mathrm{mmol} / \mathrm{kg} \mathrm{pH} 10$

C

\begin{tabular}{|c|c|c|c|c|c|c|c|c|c|}
\hline & \multicolumn{8}{|c|}{ Absorbance } \\
\hline & & Water & $\begin{array}{l}290 \mathrm{mmol} / \mathrm{kg} \\
\mathrm{pH} 7.4\end{array}$ & $\begin{array}{l}50 \mathrm{mmol} / \mathrm{kg} \\
\mathrm{pH} 4\end{array}$ & $\begin{array}{l}50 \mathrm{mmol} / \mathrm{kg} \\
\mathrm{pH} 7\end{array}$ & $\begin{array}{l}50 \mathrm{mmol} / \mathrm{kg} \\
\mathrm{pH} 10\end{array}$ & $\begin{array}{l}500 \mathrm{mmol} / \mathrm{kg} \\
\mathrm{pH} 4\end{array}$ & $\begin{array}{l}500 \mathrm{mmol} / \mathrm{kg} \\
\mathrm{pH} 7\end{array}$ & $\begin{array}{l}500 \mathrm{mmol} / \mathrm{kg} \\
\mathrm{pH} 10\end{array}$ \\
\hline \multirow{3}{*}{ Wavelength $(\mathrm{nm})$} & 280 & 0.367 & 0.203 & 0.226 & 0.223 & 0.251 & 0.226 & 0.230 & 0.243 \\
\hline & 320 & 0.126 & 0.000 & 0.000 & 0.003 & 0.000 & 0.003 & 0.006 & 0.001 \\
\hline & 350 & 0.117 & 0.000 & 0.001 & 0.002 & 0.001 & 0.004 & 0.006 & 0.000 \\
\hline
\end{tabular}

Fig. 2. UV scans to determine the effect of $\mathrm{pH}$ and ionic strength on GRFT $(250 \mu \mathrm{g} / \mathrm{mL})$. GRFT solutions in water, $\mathrm{pH} 4$, $\mathrm{pH} 7$, and $\mathrm{pH} 10$ buffers were analyzed by UV spectroscopy to determine the formation of insoluble aggregates. a GRFT solutions prepared in low ionic strength buffers $(50 \mathrm{mOsm} / \mathrm{kg})$. b GRFT solutions prepared in high ionic strength buffers (500 mOsm $/ \mathrm{kg}$ ). c Absorbance values at 280, 320, and $350 \mathrm{~nm}$. The trend lines largely overlap due to the similar absorbance of the different samples at each $\mathrm{pH}$

GRFT, respectively. GRFT was not quantifiable with RPHPLC in the receptor samples at any time point for any of the specimens.

Under the current experimental set-up, GRFT (labeled and unlabeled) was found to adhere to the surface (superficial layer) of the cervical epithelium (Fig.5a, b). No gross morphological changes were observed upon H\&E staining between pre-tissue and post-tissue.

\section{Compatibility with Lactobacillus}

GRFT was exposed in vitro to three strains of Lactobacillus that are present within the normal, healthy human vaginal environment. As shown in Fig. 5c, GRFT caused $<10$-fold change in bacterial growth across all three strains, suggesting compatibility between GRFT and the bacteria.

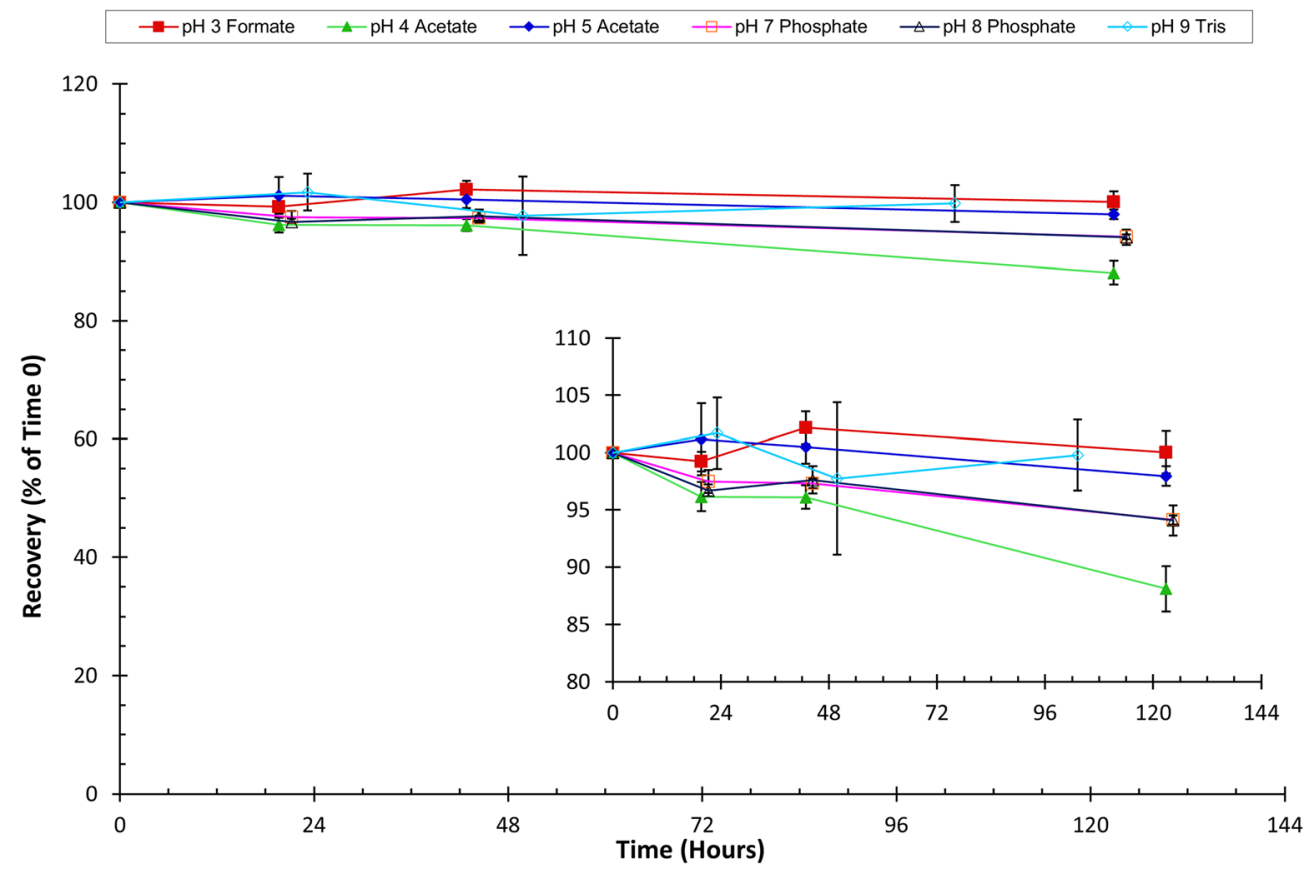

Fig. 3. GRFT stability in pH-buffered solutions. GRFT $(450 \mu \mathrm{g} / \mathrm{mL})$ stability in buffered solutions over the $\mathrm{pH}$ range of 3 to 9 was monitored via HPLC detection. The inset is included to better display the $\mathrm{pH}$ stability trends 
a

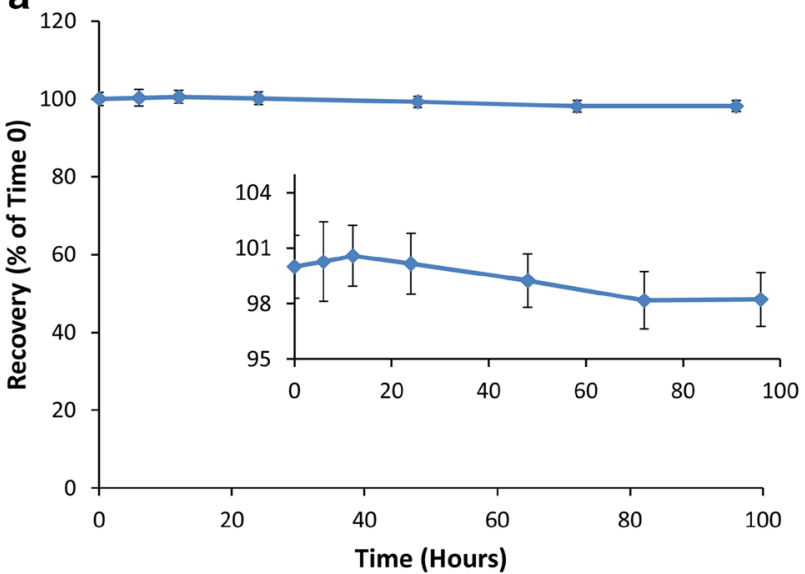

b

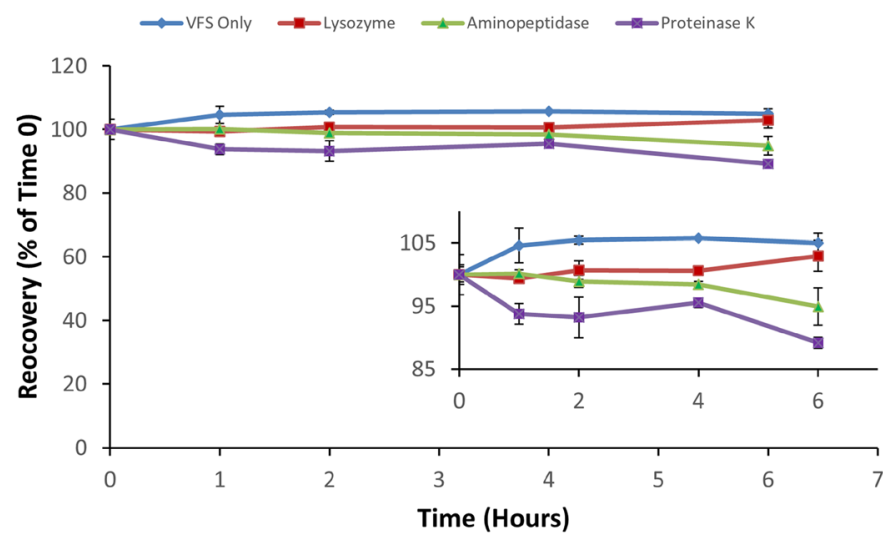

Fig. 4. GRFT stability in a vaginal fluid simulant (VFS) (with an inset) and b enzymes commonly present in human cervicovaginal lavage (CVL) (with an inset). GRFT (450 $\mathrm{g} / \mathrm{mL}$ ) in VFS and in each of the three enzymes (aminopeptidase $100 \mathrm{U} / \mathrm{mL}$, lysozyme $100,000 \mathrm{U} / \mathrm{mL}$, and proteinase $\mathrm{K} 100 \mathrm{U} / \mathrm{mL}$ ) was monitored at $37{ }^{\circ} \mathrm{C}$ for 4 days and $6 \mathrm{~h}$, respectively. GRFT concentration was monitored via HPLC fluorescence detection

\section{Oxidation in Hydrogen Peroxide and CVL}

After $24 \mathrm{~h}$ of exposure to $0.02 \% \mathrm{H}_{2} \mathrm{O}_{2}$, the parent GRFT peak (denoted as Peak A, RRT 1.000) disappeared, and the chromatogram showed approximately $8 \%$ Peak B (RRT 0.900) and $92 \%$ Peak C (RRT 0.690), suggesting complete degradation of GRFT. GRFT degraded in a similar fashion when exposed to human CVL. Representative HPLC chromatograms of samples subjected to $\mathrm{H}_{2} \mathrm{O}_{2}$ and CVL exposures are shown in Fig. 6a.
To further investigate GRFT degradation by $\mathrm{H}_{2} \mathrm{O}_{2}$ and human CVL, intact mass analyses of peaks $\mathrm{A}, \mathrm{B}$, and $\mathrm{C}$ from both exposures; peptide sequencing of GRFT peaks A and $\mathrm{C}$ of $\mathrm{H}_{2} \mathrm{O}_{2}$ exposure; and gp120 binding activity of peaks $\mathrm{A}, \mathrm{B}$, and $\mathrm{C}$ from both exposures were performed. Representative intact mass spectra are shown in Fig. $6 \mathrm{~b}$, c for $\mathrm{H}_{2} \mathrm{O}_{2}$-treated samples. All the intact masses detected by mass spectrometry are summarized in Table I.

The intact mass of recombinant GRFT was determined to be $12,732.2 \mathrm{Da}$, in agreement with the published sequence a

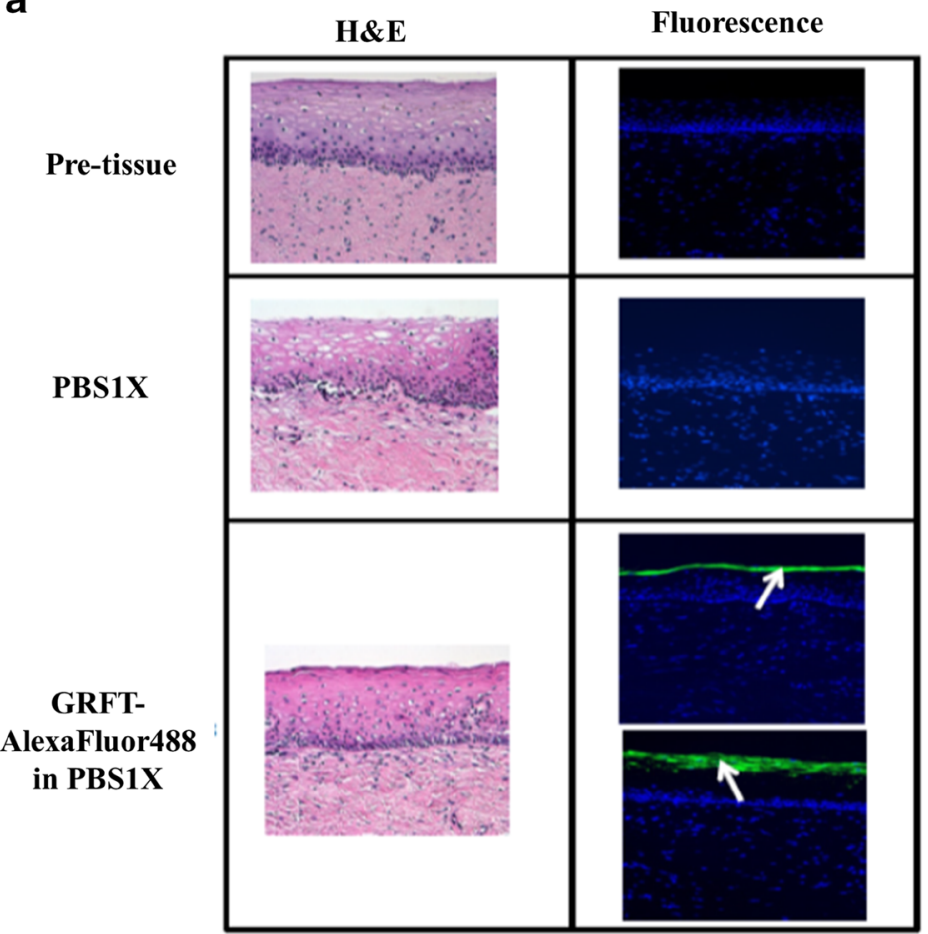

b

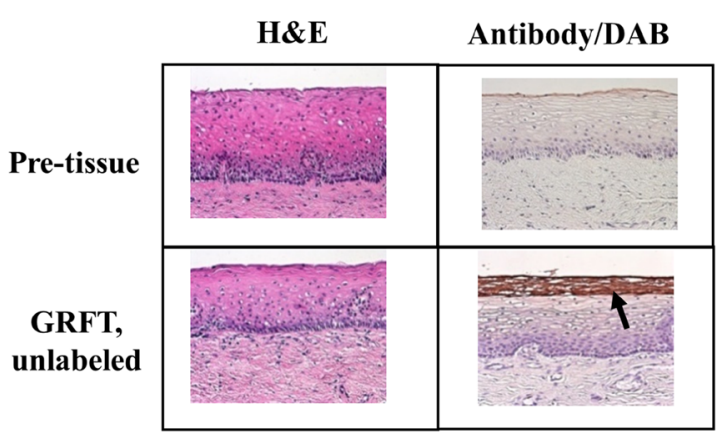

C

\begin{tabular}{|l|c|}
\hline Lactobacillus Strain $^{\mathbf{a}}$ & $\begin{array}{c}\text { Viability Reduction } \\
\text { (log difference) }\end{array}$ \\
\hline L. crispatus ATCC 33197 & 0.0211 \\
\hline L. jensenii ATCC 25258 & 0.0588 \\
\hline L. jensenii LBP 28Ab & 0.0298 \\
\hline
\end{tabular}

Fig. 5. Cervical tissue microscopy of a GRFT-AlexaFluor488 and b unlabeled GRFT, and GRFT compatibility with lactobacilli (c). Representative H\&E (first column) and fluorescence (FITC and DAPI filter overlay; second column) micrographs (a) or Antibody/DAB staining (second column) micrographs (b) are shown. GRFT tissue localization is represented by green fluorescence, as indicated by the white arrows (a) or by reddish-brown coloring, as indicated by the black arrow (b). Micrographs were taken with a $\times 20$ objective for both $\mathbf{a}$ and $\mathbf{b}$ 

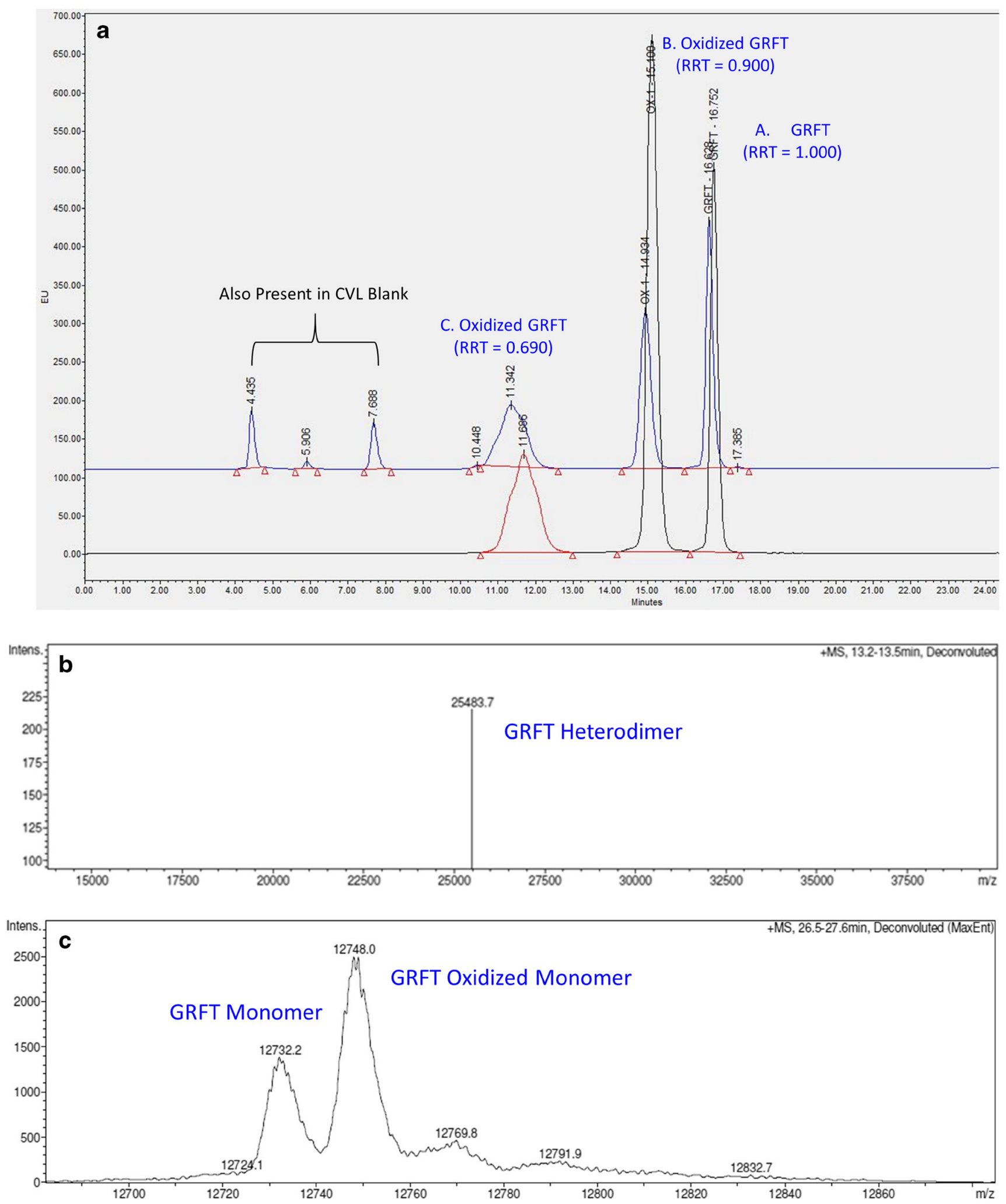

Fig. 6. Oxidation of GRFT after exposure to $0.02 \%$ hydrogen peroxide (H2O2) and CVL. a Representative chromatograms and b-c representative intact masses observed after the exposure. HPLC chromatograms of GRFT exposed to H2O2 and human CVL (separately) are overlaid in order to visually compare the chromatographic similarity (a). The bottom (black line) chromatogram represents GRFT in $0.02 \%$ $\mathrm{H} 2 \mathrm{O} 2$ at $5 \mathrm{~h}$. The upper (blue line) chromatogram represents GRFT in human CVL at $2.5 \mathrm{~h}$ of exposure. Peak A is GRFT. Peaks B and C are oxidative products of GRFT. The extra peaks in CVL were also present in the CVL blank; therefore, they were not GRFT related. Mass spectrometric analysis of the $\mathrm{H} 2 \mathrm{O} 2$ peak B identifies three species with intact masses corresponding to the heterodimer (b) and two monomers (c), respectively 
Table I. Summary of GRFT Intact Mass Analyses

Homodimer Heterodimer-one Monomer Oxidized $(25466 \pm 4$ monomer oxidized $(12733 \pm 2$ monomer Da) $\quad(25482 \pm 4 \mathrm{Da}) \quad \mathrm{Da}) \quad(12749 \pm 2$ $\mathrm{Da})$

\begin{tabular}{|c|c|c|c|}
\hline $\begin{array}{ll}\text { GRFT X } & \text { X } \\
\mathrm{H}_{2} \mathrm{O}_{2} & \\
\text { peak A } & \end{array}$ & & $X$ & \\
\hline $\begin{array}{l}\text { GRFT } \\
\mathrm{H}_{2} \mathrm{O}_{2} \\
\text { peak B }\end{array}$ & $\mathrm{X}$ & $X$ & $\mathrm{X}$ \\
\hline $\begin{array}{l}\text { GRFT } \\
\mathrm{H}_{2} \mathrm{O}_{2} \\
\text { peak C }\end{array}$ & & & $X$ \\
\hline $\begin{array}{l}\text { GRFT } \\
\text { C V L } \\
\text { peak A }\end{array}$ & & $X$ & \\
\hline $\begin{array}{l}\text { GRFT } \\
\text { C V L } \\
\text { peak B }\end{array}$ & & $X$ & $X$ \\
\hline $\begin{array}{l}\text { GRFT } \\
\text { C V L } \\
\text { peak C }\end{array}$ & & & $X$ \\
\hline
\end{tabular}

of GRFT isolated from red alga Griffithsia sp. except that the unknown residue $X$ at position 31 was replaced with alanine (A) (underlined) (2).

SLTHRKFGGS

GGSPFSGLSS

IAVRSGSYLD

AIIIDGVHHG

GSGGNLSPTF

TFGSGEYISN

MTIRSGDYID

NISFETNMGR

RFGPYGGSGG

SANTLSNVKV

IQINGSAGDY

LDSLDIYYEQ

$\mathrm{Y}$

In the GRFT sample exposed to $\mathrm{H}_{2} \mathrm{O}_{2}$, peak A contained unmodified monomer and its dimer (homodimer) as expected; peak B contained both unmodified and oxidized monomers as well as their dimer (heterodimer), suggesting partial oxidation, and peak $\mathrm{C}$ contained only oxidized monomer (Table I). In the GRFT sample exposed to CVL, peaks $\mathrm{A}, \mathrm{B}$, and $\mathrm{C}$ contained unmodified monomer, a mixture of unmodified and oxidized monomers, and oxidized monomer, respectively (Table I). Therefore, oxidation was found to be the major degradation pathway of GRFT when subjected to oxidative stress. The site of oxidation was found to be methionine 78 (bold and underlined in the sequence listed above) by peptide sequencing of the GRFT peak $\mathrm{C}$ from $\mathrm{H}_{2} \mathrm{O}_{2}$ exposure.

The oxidized samples were subjected to gp120 binding ELISA experiments. Our preliminary results showed that all $\mathrm{H}_{2} \mathrm{O}_{2}$ oxidative samples (peaks $\mathrm{A}, \mathrm{B}, \mathrm{C}$ ) had \% binding curves comparable with each other and to the GRFT standard, but CVL oxidative samples displayed binding curves that were shifted to the right (data not shown), indicating decreased GRFT-gp120 binding in these three CVL samples.

It should be noted that several antioxidant excipients were investigated for their potential to prevent GRFT from oxidation. However, none of the amino acids, vitamin $\mathrm{E}$ TPGS, or the chelating agent EDTA afforded any significant protection from protein oxidation (data not shown).

\section{Long-Term Stability}

The long-term aggregation, degradation, oxidation, melting temperature, and potency (i.e., gp120-binding affinity) of GRFT were evaluated using SEC-HPLC, RP-HPLC, DSF, gp120 binding ELISA and SPR. Using these analytical procedures, the physical, chemical, thermal and functional stability of GRFT was evaluated for GRFT stored at $4{ }^{\circ} \mathrm{C}$ and $25^{\circ} \mathrm{C}$ up to 24 months.

The GRFT drug substance formulated in PBS was found to be free of protein aggregation or degradation by SECHPLC analysis, and good stability was maintained after storage at $4^{\circ} \mathrm{C}$ and $25^{\circ} \mathrm{C}$ (oxidation $<2.5 \%$ and $<6.5 \%$, respectively) for 2 years (Fig. 7; Table II). Additionally, no significant change in the potency or thermostability of GRFT was found. GRFT was shown via RP-HPLC to be oxidized by approximately $1 \%$ and $5 \%$ during storage at $4^{\circ} \mathrm{C}$ and $25^{\circ} \mathrm{C}$, respectively.

\section{DISCUSSION}

All pharmaceutical products need to maintain physical, chemical, thermal, and functional stability during storage, formulation, and delivery. During all of our preformulation assessments except oxidative stress (see more discussions below), GRFT proved to be a stable protein. GRFT was found to be thermally stable under $\leq 40^{\circ} \mathrm{C} / 75 \% \mathrm{RH}$ but degraded quickly at $65^{\circ} \mathrm{C}$ (Fig. 1). Given its proteinaceous nature, GRFT is likely to have undergone denaturation during the duration of exposure at this elevated temperature. However, it should be noted that it is unlikely that GRFT will be exposed to temperatures as high as $65^{\circ} \mathrm{C}$ during its formulation manufacturing or dosage form administration/ use.

GRFT remained stable when exposed to light, freezethaw cycling, physical agitation (data not shown), different ionic strengths (Fig. 2), and even strong acid (1N $\mathrm{HCl})$ and strong base $(1 \mathrm{~N} \mathrm{NaOH})$ (data not shown). Its stability was maintained in different buffered solutions at $\mathrm{pH}$ of $3,5,7,8$, and 9 (Fig. 3). However, degradation was observed at $\mathrm{pH} 4$ no matter whether the solution was acetate or phosphate buffered. The GRFT samples in $\mathrm{pH} 4$ buffers became cloudy either upon initiation of the study or shortly after, suggesting reduced solubility, which in turn caused the decreased recovery at $\mathrm{pH} 4$. This type of non-monotonic behavior has been observed by Zhang et al. (41) for a recombinant therapeutic antibody. The isoelectric point (pI) is 7.2 for this antibody. At pH 5.3, far below its pI, when the ionic strength was increased, the antibody underwent an initial solubility decrease followed by a solubility increase, which was contributed to anion binding and its charge neutralization effect. 


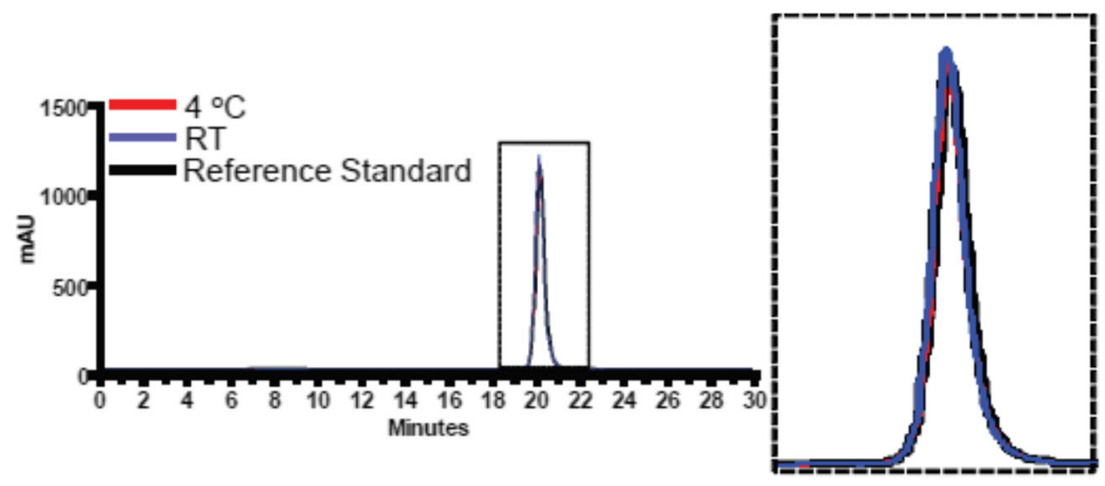

Fig. 7. Representative SEC-HPLC chromatogram for long-term stability. GRFT was stored at $4{ }^{\circ} \mathrm{C}$ and $25^{\circ} \mathrm{C}(\mathrm{RT})$ and compared to the reference standard. The $4{ }^{\circ} \mathrm{C}$ and $25^{\circ} \mathrm{C}$ profiles overlap with each other, and they each overlap with the reference standard. The overlaid peaks represent the GRFT dimer mass of approximately $25 \mathrm{kDa}$

A vaginally applied product, like a vaginal microbicide, should not exert any harmful effects on the innate commensal microflora or tissue of the cervicovaginal environment. GRFT was found to be stable in VFS (Fig. 4a). Enzymes commonly found within the human vagina did not degrade GRFT (Fig. 4b), which was similar to the findings of Moncla et al. (42), who evaluated the impact of nine proteases on GRFT and found eight of them could not digest/degrade GRFT. Additionally, GRFT was found to adhere to, instead of penetrating through the cervical epithelium (Fig. 5a, b). This was consistent with the previous report that GRFTAlexaFluor488 adhered to the surface of Ect1/E6E7 cells, a human ectocervical cell line (40). These results indicate that GRFT will remain in the vaginal lumen, coating but not harming, the surface of an intact cervical epithelium. Furthermore, GRFT did not affect the viability of three stains of commensal Lactobacillus spp. present in the normal human vagina (Fig. 5c). These observations, taken together, provide evidence of GRFT's safety profile.
When stressed with $0.02 \% \mathrm{H}_{2} \mathrm{O}_{2}$ or exposed to human CVL, GRFT was found to be degraded to products with shorter retention times on RP-HPLC (Fig. 6a). Mass spectrometric analysis revealed that GRFT was partially oxidized upon exposure to either $\mathrm{H}_{2} \mathrm{O}_{2}$ or human CVL (Fig. 6b, c; Table I), and the oxidation occurred on methionine 78 .

Due to the complex nature of human cervicovaginal secretions, there was initial concern that proteins in the CVL may interfere with the mass spectrometry detection of GRFT proteins in this sample matrix. No such interference was found. However, the CVL samples appeared to have lower than expected concentrations when subjected to intact mass analyses. Therefore, the samples had to be concentrated. GRFT is a lectin and binds to mannose, glucose, and $N$-acetyl glucosamine (2). The apparently low GRFT protein concentrations detected in the CVL may potentially be due to the non-specific binding between GRFT and CVL components, such as mucins $(34,43)$ or cellular debris $(40)$, which leaves only unbound GRFT available for RP-HPLC detection/

Table II. Combined Real-Time Stability Data

\begin{tabular}{|c|c|c|c|c|c|}
\hline Time (month) & SEC-purity (\%) & Oxidation peak (\%) & $\mathrm{T}_{\mathrm{m}}\left({ }^{\circ} \mathrm{C}\right)$ & $\mathrm{EC}_{50}(\mathrm{ng} / \mathrm{ml})$ & $\mathrm{K}_{\mathrm{d}}(\mathrm{M})$ \\
\hline \multicolumn{6}{|c|}{$4^{\circ} \mathrm{C}$} \\
\hline 0 & $99.9 \pm 0$ & $1.23 \pm 0.02$ & $77.7 \pm 0.9$ & 8.7 & $3.19 \mathrm{e}-08 \pm 1.76 \mathrm{e}-09$ \\
\hline 1 & $99.9 \pm 0$ & $1.05 \pm 0.09$ & $76.9 \pm 0.8$ & 12.4 & $3.11 \mathrm{e}-08 \pm 9.77 \mathrm{e}-10$ \\
\hline 3 & $99.9 \pm 0$ & $1.16 \pm 0.05$ & $74.2 \pm 3.9$ & 8.7 & $3.22 \mathrm{e}-08 \pm 1.63 \mathrm{e}-09$ \\
\hline 6 & $99.9 \pm 0$ & $1.31 \pm 0.05$ & $78.3 \pm 1.4$ & 5.4 & $3.46 \mathrm{e}-08 \pm 3.07 \mathrm{e}-09$ \\
\hline 9 & $99.9 \pm 0$ & $1.35 \pm 0.01$ & $78.5 \pm 0.2$ & 9.5 & $3.47 \mathrm{e}-08 \pm 2.07 \mathrm{e}-09$ \\
\hline 12 & $99.9 \pm 0$ & $1.24 \pm 0.02$ & $78.2 \pm 0.2$ & 31.1 & $3.04 \mathrm{e}-08 \pm 4.61 \mathrm{e}-10$ \\
\hline 18 & $99.8 \pm 0$ & $2.39 \pm 0.02 *$ & $78.7 \pm 0.1$ & 9.8 & $2.43 \mathrm{e}-08 \pm 3.07 \mathrm{e}-09$ \\
\hline 24 & $99.8 \pm 0$ & $2.10 \pm 0.08$ & $78.5 \pm 0.1$ & 14.9 & $2.46 \mathrm{e}-08 \pm 1.75 \mathrm{e}-09$ \\
\hline \multicolumn{6}{|c|}{$25^{\circ} \mathrm{C}$} \\
\hline 0 & $99.9 \pm 0$ & $1.23 \pm 0.02$ & $77.7 \pm 0.9$ & 8.7 & $3.19 \mathrm{e}-08 \pm 1.76 \mathrm{e}-09$ \\
\hline 1 & $99.9 \pm 0$ & $1.34 \pm 0.06$ & $76.8 \pm 1.2$ & 10.4 & $3.17 \mathrm{e}-08 \pm 1.33 \mathrm{e}-09$ \\
\hline 3 & $99.9 \pm 0$ & $1.76 \pm 0.02$ & $76.8 \pm 0.9$ & 10 & $3.30 \mathrm{e}-08 \pm 1.29 \mathrm{e}-09$ \\
\hline 6 & $99.9 \pm 0$ & $2.13 \pm 0.05$ & $79.4 \pm 0.9$ & 5.1 & $3.40 \mathrm{e}-08 \pm 2.09 \mathrm{e}-09$ \\
\hline 9 & $99.9 \pm 0$ & $2.57 \pm 0.02$ & $77.9 \pm 2.4$ & 10.2 & $3.56 \mathrm{e}-08 \pm 1.64 \mathrm{e}-09$ \\
\hline 12 & $99.9 \pm 0$ & $2.78 \pm 0.06$ & $78.5 \pm 0.3$ & 13.4 & $3.29 \mathrm{e}-08 \pm 1.71 \mathrm{e}-09$ \\
\hline 18 & $99.8 \pm 0$ & $5.37 \pm 0.04 *$ & $78.9 \pm 0.2$ & 10.4 & $2.35 \mathrm{e}-08 \pm 2.25 \mathrm{e}-10$ \\
\hline 24 & $99.8 \pm 0$ & $6.19 \pm 0.97$ & $78.7 \pm 0.1$ & 6.9 & $2.38 \mathrm{e}-08 \pm 1.42 \mathrm{e}-09$ \\
\hline
\end{tabular}

*Oxidation by RF-HPLC was measure at 20 months instead of 18 months 
quantification. Similarly, only unbound GRFT is available for gp120 binding. Therefore, it is not surprising that reduced gp120 binding activity was observed for the CVL exposed GRFT samples (data not shown).

This oxidative degradation pathway and decreased gp120 binding activity of CVL-exposed oxidative products needs to be taken into consideration prior to or during formulation studies. Unfortunately, our initial efforts on antioxidant screening failed to find an effective antioxidant that could protect GRFT from oxidation. Therefore, further studies are required to eliminate or minimize oxidation. These studies could include screening additional antioxidant agents or explore alternative approaches such as mutating methionine 78 to a non-oxidable residue.

Shelf-life stability studies further proved GRFT to be a stable protein except that it is prone to oxidation (Fig. 7; Table II). The extent of oxidation was higher at $25^{\circ} \mathrm{C}$ than at $4^{\circ} \mathrm{C}$. Nevertheless, our analysis indicated that GRFT maintained molecular stability and gp120-binding affinity upon storage at both $4{ }^{\circ} \mathrm{C}$ and $25^{\circ} \mathrm{C}$ over 2 years, suggesting that oxidation of methionine 78 may not constitute a critical quality attribute that affects the protein's efficacy. Its potential impact on safety, however, remains to be determined.

In summary, we identified several factors (i.e. temperature, $\mathrm{pH}$, oxidation, and non-specific binding) that should be taken into consideration for GRFT-based dosage forms. GRFT should be kept below $65^{\circ} \mathrm{C}$ and $\mathrm{pH}$ adjusted (preferably to $>6.5$ ). Excipients with oxidizing or GRFT-binding potential should be avoided or kept to the minimum amount. An approach that can effectively minimize oxidation would have to be found prior to or during formulating GRFT into a microbicide product.

\section{CONCLUSION}

In this preformulation work, GRFT was demonstrated to be a stable protein with good physical, chemical, and biological stability profiles under stressed conditions. It also showed good physical, thermal, or biological stability after 2 years of storage in PBS at $4^{\circ} \mathrm{C}$ and $25^{\circ} \mathrm{C}$. The protein did not penetrate through the cervical epithelium or show antimicrobial activity against the commensal Lactobacillus spp., demonstrating two desirable characteristics of biological safety. One issue of concern is oxidation. In the GRFT sequence, methionine 78 is susceptible to oxidation when exposed to $\mathrm{H}_{2} \mathrm{O}_{2}$ or human CVL. Slow oxidation was also observed after long-term storage. Several antioxidants commonly used in pharmaceutical products were screened, but none of them could prevent GRFT from oxidation. More studies are required to find an effective approach that protects GRFT from oxidation during storage, formulation, and delivery.

\section{ACKNOWLEDGEMENTS}

We would like to graciously thank Guy Uechi of the Biomedical Mass Spectrometry Center at the University of Pittsburgh for his analytical support of the intact mass analysis and peptide sequencing experiments.

\section{FUNDING}

The research described was kindly supported by the National Institute of Allergy and Infectious Diseases (NIAID) at the National Institute of Health through grant R01AI076169 and U19AI113182.

\section{DECLARATIONS}

Disclaimer The contents of this manuscript are solely the responsibility of the authors and do not necessarily represent the official views of the NIAID.

\section{REFERENCES}

1. UNAIDS. Fact Sheet - Global AIDS Update 20192019 [Available from: https://www.unaids.org/en/resources/fact-sheet.

2. Mori T, O'Keefe BR, Sowder RC 2nd, Bringans S, Gardella R, Berg $\mathrm{S}$, et al. Isolation and characterization of griffithsin, a novel HIV-inactivating protein, from the red alga Griffithsia sp. J Biol Chem. 2005;280(10):9345-53.

3. O'Keefe BR, Vojdani F, Buffa V, Shattock RJ, Montefiori DC, Bakke J, et al. Scaleable manufacture of HIV-1 entry inhibitor griffithsin and validation of its safety and efficacy as a topical microbicide component. Proc Natl Acad Sci U S A. 2009;106(15):6099-104.

4. Barton C, Kouokam JC, Lasnik AB, Foreman O, Cambon A, Brock G, et al. Activity of and effect of subcutaneous treatment with the broad-spectrum antiviral lectin griffithsin in two laboratory rodent models. Antimicrob Agents Chemother. 2014;58(1):120-7.

5. Alexandre KB, Gray ES, Lambson BE, Moore PL, Choge IA, Mlisana K, et al. Mannose-rich glycosylation patterns on HIV-1 subtype C gp120 and sensitivity to the lectins, Griffithsin. Cyanovirin-N and Scytovirin. Virology. 2010;402(1):187-96.

6. Férir G, Huskens D, Palmer KE, Boudreaux DM, Swanson MD, Markovitz DM, et al. Combinations of griffithsin with other carbohydrate-binding agents demonstrate superior activity against HIV type 1, HIV type 2, and selected carbohydratebinding agent-resistant HIV Type 1 strains. AIDS Res Hum Retroviruses. 2012;28(11):1513-23.

7. Barton C, Kouokam JC, Hurst H, Palmer KE. Pharmacokinetics of the antiviral lectin griffithsin administered by different routes indicates multiple potential uses. Viruses. 2016;8(12).

8. Levendosky K, Mizenina O, Martinelli E, Jean-Pierre N, Kizima L, Rodriguez A, et al. Griffithsin and carrageenan combination to target herpes simplex virus 2 and human papillomavirus. Antimicrob Agents Chemother. 2015;59(12):7290-8.

9. Nixon B, Stefanidou M, Mesquita PMM, Fakioglu E, Segarra T, Rohan L, et al. Griffithsin protects mice from genital herpes by preventing cell-to-cell spread. Journal of Virology. 2013;87(11):6257-69.

10. Lo MK, Spengler JR. Krumpe LRH. Chattopadhyay A, Harmon JR, et al. Griffithsin inhibits Nipah virus entry and fusion and can protect Syrian golden hamsters from lethal Nipah virus challenge. J Infect Dis: Welch SR; 2020.

11. Meuleman P, Albecka A, Belouzard S, Vercauteren K, Verhoye L, Wychowski C, et al. Griffithsin has antiviral activity against hepatitis $\mathrm{C}$ virus. Antimicrobial agents and chemotherapy. 2011;55(11):5159-67.

12. Takebe Y, Saucedo CJ, Lund G, Uenishi R, Hase S, Tsuchiura $\mathrm{T}$, et al. Antiviral lectins from red and blue-green algae show potent in vitro and in vivo activity against hepatitis $\mathrm{C}$ virus. PLoS One. 2013;8(5):e64449. 
13. Ishag HZA, Li C, Huang L. Sun M-x, Wang F, Ni B, et al. Griffithsin inhibits Japanese encephalitis virus infection in vitro and in vivo. Archives of Virology. 2013;158(2):349-58.

14. Ishag HZA, Li C, Wang F, Mao X. Griffithsin binds to the glycosylated proteins (E and prM) of Japanese encephalitis virus and inhibit its infection. Virus Research. 2016;215:50-4.

15. O'Keefe BR, Giomarelli B, Barnard DL, Shenoy SR, Chan PK, McMahon JB, et al. Broad-spectrum in vitro activity and in vivo efficacy of the antiviral protein griffithsin against emerging viruses of the family Coronaviridae. J Virol. 2010;84(5):2511-21.

16. Millet JK, Seron K, Labitt RN, Danneels A, Palmer KE, Whittaker GR, et al. Middle East respiratory syndrome coronavirus infection is inhibited by griffithsin. Antiviral Res. 2016;133:1-8.

17. Mitchell CA, Ramessar K, O'Keefe BR. Antiviral lectins: selective inhibitors of viral entry. Antiviral research. 2017;142:37-54.

18. Lusvarghi S, Bewley CA. Griffithsin: an antiviral lectin with outstanding therapeutic potential. Viruses. 2016;8(10).

19. Lee C. Griffithsin, a highly potent broad-spectrum antiviral lectin from red algae: from discovery to clinical application. Mar Drugs. 2019;17(10):567.

20. Emau P, Tian B, O'Keefe BR, Mori T, McMahon JB, Palmer $\mathrm{KE}$, et al. Griffithsin, a potent HIV entry inhibitor, is an excellent candidate for anti-HIV microbicide. Journal of medical primatology. 2007;36(4-5):244-53.

21. Ziolkowska NE, Shenoy SR, O'Keefe BR, McMahon JB, Palmer KE, Dwek RA, et al. Crystallographic, thermodynamic, and molecular modeling studies of the mode of binding of oligosaccharides to the potent antiviral protein griffithsin. Proteins. 2007;67(3):661-70.

22. Ziolkowska NE, Shenoy SR, O'Keefe BR, Wlodawer A. Crystallographic studies of the complexes of antiviral protein griffithsin with glucose and $\mathrm{N}$-acetylglucosamine. Protein Sci. 2007;16(7):1485-9.

23. Population Council [Available from: https://www.popcouncil.org/.

24. Derby N, Lal M, Aravantinou M, Kizima L, Barnable P, Rodriguez A, et al. Griffithsin carrageenan fast dissolving inserts prevent SHIV HSV-2 and HPV infections in vivo. Nat Commun. 2018;9(1):3881.

25. Girard L, Birse K, Holm JB, Gajer P, Humphrys MS, Garber D, et al. Impact of the griffithsin anti-HIV microbicide and placebo gels on the rectal mucosal proteome and microbiome in nonhuman primates. Sci Rep. 2018;8(1):8059.

26. Grooms TN, Vuong HR, Tyo KM, Malik DA, Sims LB, Whittington CP, Palmer KE, Matoba N, Steinbach-Rankins JM Griffithsin-modified electrospun fibers as a delivery scaffold to prevent HIV infection. Antimicrob Agents Chemother. 2016;60(11):6518-6531, Griffithsin-Modified Electrospun Fibers as a Delivery Scaffold To Prevent HIV Infection.

27. Lal M, Lai M, Ugaonkar S, Wesenberg A, Kizima L, Rodriguez A, et al. Development of a vaginal fast-dissolving insert combining griffithsin and carrageenan for potential use against sexually transmitted infections. J Pharm Sci. 2018;107(10):260110.

28. Nixon B, Stefanidou M, Mesquita PM, Fakioglu E, Segarra T, Rohan L, et al. Griffithsin protects mice from genital herpes by preventing cell-to-cell spread. J Virol. 2013;87(11):6257-69.
29. Tyo KM, Duan J. Kollipara P. Lee D, Palmer KE, et al. pHresponsive delivery of griffithsin from electrospun fibers. Eur J Pharm Biopharm: Dela Cerna MVC; 2018.

30. Vuong HR, Tyo KM, Steinbach-Rankins JM. Fabrication and characterization of griffithsin-modified fiber scaffolds for prevention of sexually transmitted infections. J Vis Exp. 2017;128.

31. Lemert M, Mastroianni L Jr. Cervical factors in infertility. Clin Obstet Gynecol. 1974;17(4):29-43.

32. Schumacher GF, Kim MH, Hosseinian AH, Dupon C. Immunoglobulins, proteinase inhibitors, albumin, and lysozyme in human cervical mucus. I. Communication: hormonal profiles and cervical mucus changes-methods and results. Am J Obstet Gynecol. 1977;129(6):629-36.

33. Moghissi KS, Syner FN, Borin B. Cyclic changes of cervical mucus enzymes related to the time of ovulation II. Amino peptidase and esterase. Obstet Gynecol. 1976;48(3):347-50.

34. Moncla BJ, Chappell C, Mahal LK, Debo BM, Meyn L, Hillier $\mathrm{S}$. Impact of bacterial vaginosis as assessed by Nugent score and hormonal status on glycosidases and lectin binding in cervicovaginal lavage samples. PLoS One. 2015;accepted; PONE-D-15-01714.

35. Briselden AM, Moncla BJ, Stevens CE, Hillier SL. Sialidases (neuraminidases) in bacterial vaginosis and bacterial vaginosisassociated microflora. J Clin Microbiol. 1992;30(3):663-6.

36. Rajan N, Cao Q, Anderson BE, Pruden DL, Sensibar J, Duncan $\mathrm{JL}$, et al. Roles of glycoproteins and oligosaccharides found in human vaginal fluid in bacterial adherence. Infect Immun. 1999;67(10):5027-32.

37. Valore EV, Park $\mathrm{CH}$, Igreti SL, Ganz T. Antimicrobial components of vaginal fluid. Am J Obstet Gynecol. 2002;187(3):561-8.

38. Owen DH, Katz DF. A vaginal fluid simulant. Contraception. 1999;59(2):91-5.

39. Moncla BJ, Pryke K, Rohan LC, Yang H. Testing of viscous anti-HIV microbicides using Lactobacillus. J Microbiol Methods. 2012;88(2):292-6.

40. Kouokam JC, Huskens D, Schols D, Johannemann A, Riedell SK, Walter W, et al. Investigation of griffithsin's interactions with human cells confirms its outstanding safety and efficacy profile as a microbicide candidate. PLoS One. 2011;6(8):e22635.

41. Zhang L, Tan H, Fesinmeyer RM, Li C, Catrone D, Le D, et al. Antibody solubility behavior in monovalent salt solutions reveals specific anion effects at low ionic strength. J Pharm Sci. 2012;101(3):965-77.

42. Moncla BJ, Pryke K, Rohan LC, Graebing PW. Degradation of naturally occurring and engineered antimicrobial peptides by proteases. Adv Biosci Biotechnol. 2011;2(6):404-8.

43. Wang L, Koppolu S, Chappell C, Moncla BJ, Hillier SL, Mahal LK. Studying the effects of reproductive hormones and bacterial vaginosis on the glycome of lavage samples from the cervicovaginal cavity. PLoS One. 2015; accepted; PONE-D-1501897.

Publisher's Note Springer Nature remains neutral with regard to jurisdictional claims in published maps and institutional affiliations. 